\title{
Definitions of Trollskär Formation and Sandön Formation in the Archipelago Sea, northern Baltic Sea
}

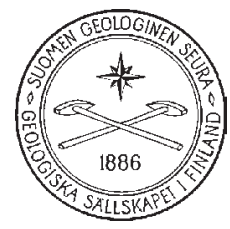

Joonas J. Virtasalo ${ }^{1,2,3)^{*}}$, Aarno T. Kotilainen ${ }^{3)}$ And

MATTI E. RÄSÄNEN ${ }^{1)}$

1) Department of Geology, FI-20014 University of Turku, Finland

2) Sektion Marine Geologie, Institut für Ostseeforschung Warnemünde, Seestrasse 15, D-18119 Rostock, Germany

3) Geological Survey of Finland, P.O. Box 96, FI-02151 Espoo, Finland

\begin{abstract}
The formal stratigraphy of Late-Quaternary late- and post-glacial sediments in the Archipelago Sea, northern Baltic Sea, is revised. The Trollskär Allomember and Sandön Allomember were previously incorrectly defined as allostratigraphic units based on an acoustic discontinuity, even though their contact is gradational in the studied sediment cores. These allostratigraphic units are formally redefined herein as the lithostratigraphic units Trollskär Formation and Sandön Formation, which belong to the Korppoo Alloformation. The purpose is to forestall misconceptions concerning temporal relationships and depositional processes at the transition of these two units.
\end{abstract}

Key words: marine geology, marine sediments, stratigraphy, allostratigraphy, lithostratigraphy, stratigraphic units, Holocene, Archipelago Sea, Baltic Sea, Finland

* Corresponding author email: joonas.virtasalo@gtk.fi

\section{Introduction}

A formal allostratigraphic division was recently presented by Virtasalo et al. (2005) for the LateQuaternary late- and post-glacial sediments of the Archipelago Sea in the northern Baltic Sea proper (Fig. 1). This depositional succession was divided into three allostratigraphic units: the Dragsfjärd Alloformation, Korppoo Alloformation and Nauvo Alloformation (Fig. 2a). These units were defined by their bounding unconformities recognized in sediment cores and acoustic profiles in accordance with guidelines in the North American Stratigraphic Code (NACSN, 2005). Korppoo Alloformation was further subdivided into the Trollskär Allomember and Sandön Allomember based on an acoustic discontinuity. However, the contact between these allomembers is gradational in the studied sediment 


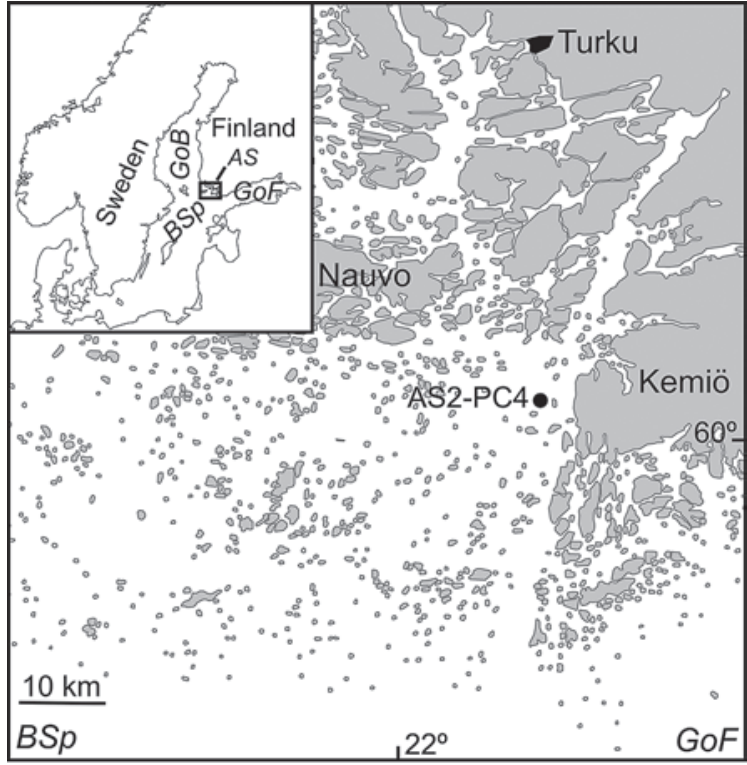

Fig. 1. Map of the study area with the AS2-PC4 sampling site indicated. $A S=$ Archipelago Sea; $B S p=$ Baltic Sea proper; GoB = Gulf of Bothnia; GoF = Gulf of Finland.

\begin{tabular}{|c|c|c|c|}
\hline \multicolumn{2}{|c|}{ A: Virtasalo et al. (2005) } & \multicolumn{2}{|c|}{ B: revised proposal } \\
\hline \multicolumn{2}{|c|}{ Nauvo Alloformation } & \multicolumn{2}{|c|}{ Nauvo Alloformation } \\
\hline \multirow{2}{*}{ 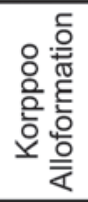 } & $\begin{array}{c}\text { Sandön } \\
\text { Allomember }\end{array}$ & \multirow{2}{*}{ 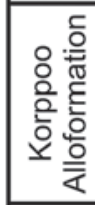 } & $\begin{array}{l}\text { Sandön } \\
\text { Formation }\end{array}$ \\
\hline & $\begin{array}{c}\text { Trollskär } \\
\text { Allomember }\end{array}$ & & $\begin{array}{l}\text { Trollskär } \\
\text { Formation }\end{array}$ \\
\hline \multicolumn{2}{|c|}{ Dragsfjärd Alloformation } & \multicolumn{2}{|c|}{ Dragsfjärd Alloformation } \\
\hline
\end{tabular}

Fig. 2. Revision of the formal stratigraphic division of Holocene late- and post-glacial sediments of Archipelago Sea. (A) Allostratigraphic division by Virtasalo et al. (2005). (B) Revised allo- and lithostratigraphic division presented herein. Solid horizontal lines indicate unconformal boundaries, while dashed lines indicate gradational contacts of the sediment units.

cores, which does not allow their definition as allostratigraphic units that, by definition, are identified by their unconformal boundaries (for reasons of this divergence from allostratigraphic principles, see Virtasalo, 2006, p. 18).

With the recent publication of the combined use of allo- and lithostratigraphy (CUAL) approach (Räsänen et al., 2009), it is time to correct the flawed definitions of these units. In the CUAL approach, regional unconformities are used for dividing a stratigraphic column into primary (allo)stratigraphic units. Lithostratigraphic units can then be used for complementing lithostratigraphically "mappable" features such as colour and texture variations in the allostratigraphic framework, where useful. The CUAL approach was developed particularly for Quaternary glacial strata, which are a relatively thin and complex overburden, making their stratigraphic classification by lithostratigraphic means difficult (Flint, 1957).

In this paper, the formal definitions of Trollskär Allomember and Sandön Allomember are retracted. These units are formally redefined as the lithostratigraphic units Trollskär Formation and Sandön Formation. The redefinitions are based on extensive high-resolution acoustic profiling and sediment-core studies presented in Virtasalo et al. (2005); the reader is referred to that study for detailed core descriptions and acoustic profiles. Depositional environments and geochronology for these units are discussed in Virtasalo et al. (2007). Their ichnofossils, diatom composition and sedimentary phosphorus forms are discussed in Virtasalo et al. (2006), Tuovinen et al. (2008), and Virtasalo \& Kotilainen (2008), respectively.

\section{Trollskär Formation}

Trollskär Formation is named after an island closest to the site where its stratotype core AS2-PC4 was collected (Fig. 1). The primary sediment structure of the unit alternates between homogeneous and laminated, with the laminae oriented in arbitrary directions (Fig. 3). The grain sizes range from clay to sand. The unit is acoustically transparent to chaotic with internal reflectors. Occasional rotated, acoustically stratified clasts are supported in the matrix. The unit is sometimes composed of acoustic beds. The external form of the unit is basin fill with the unit thickness varying from undistinguishable in the elevated areas to up to $15 \mathrm{~m}$ in the topographic depressions, being usually $4-5 \mathrm{~m}$. The unit is generally thickest in the areas with high topographic relief. The unit top is marked by a strong, hummocky acoustic reflector, showing relief at the submetre scale. Details on the sediment physical 

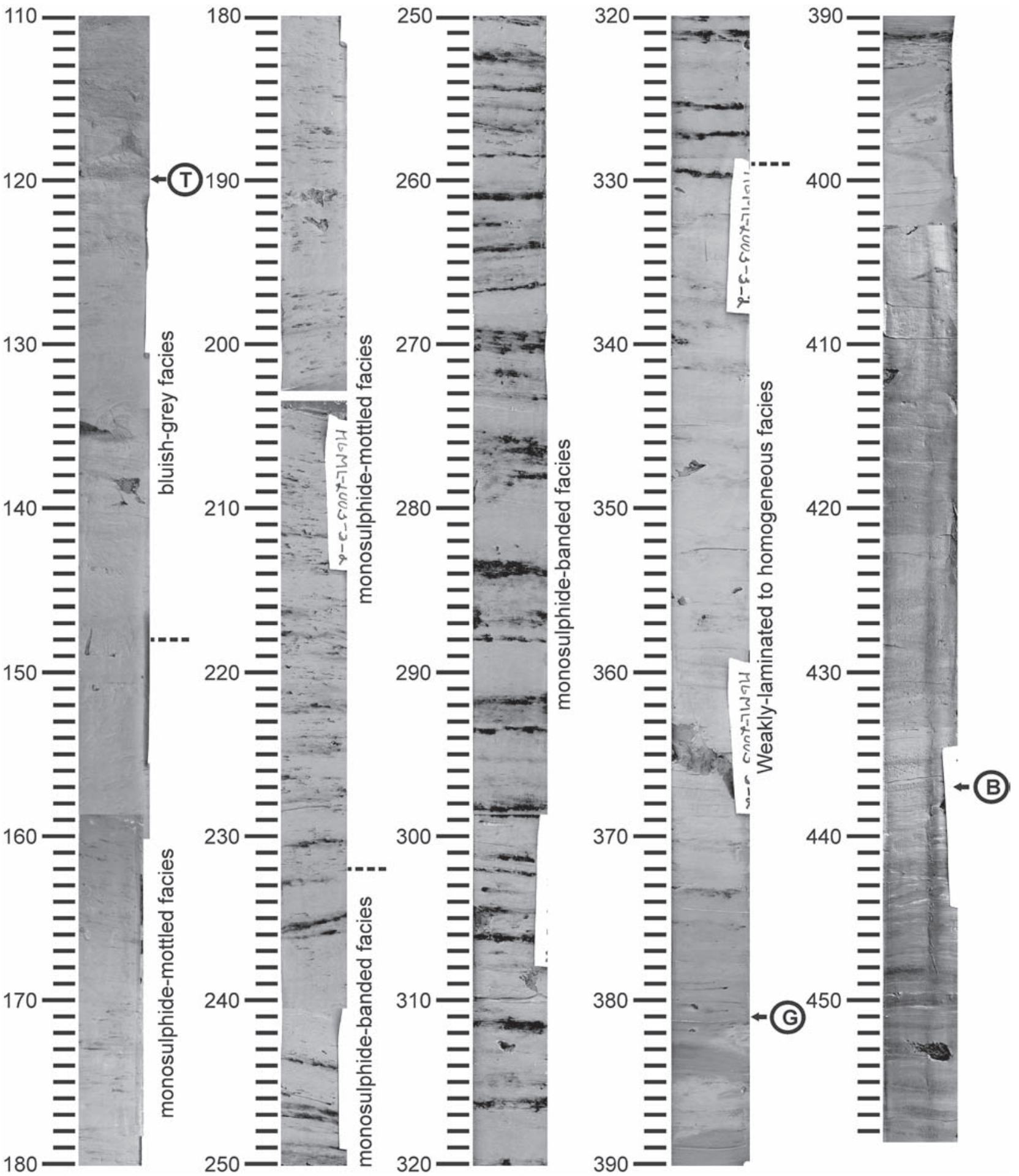

Fig. 3. Composite image of Trollskär Formation and Sandön Formation in the stratotype core AS2-PC4 (for the location, see Fig. 1). B = bottom of Trollskär Formation (erosional Dragsfjärd Alloformation / Korppoo Alloformation boundary); G = gradational Trollskär Formation / Sandön Formation contact; $\mathrm{T}$ = top of Sandön Formation (erosional Korppoo Alloformation / Nauvo Alloformation boundary). Dashed horizontal lines indicate the gradational lithofacies contacts of Sandön Formation. Vertical scale is in centimetres below the sediment surface. 
properties and acoustic characteristics are presented in Virtasalo et al. (2005). The lower boundary of the unit is erosional to the underlying Dragsfjärd Alloformation. The unit grades at the top to Sandön Formation.

Trollskär Formation is interpreted to be a cohesive debris-flow deposit (debrite) based on the chaotic arrangement of sediments, the matrix-supported sediment clasts and the irregular surface features (Virtasalo et al., 2007). Palaeoseismic activity due to glacio-isostatic rebound shortly after deglaciation has been suggested as the triggering mechanism for the debrite (Virtasalo et al., 2007; see also Kotilainen \& Hutri, 2004). The increasing unit thickness in the areas of high topographic relief, and the contained unlithified sediment clasts, indicate relatively short transport distances. Further, the wide occurrence and acoustic beds of the unit indicate that it is composed of multiple slumps and gravity flows initiated from different locations. Hutri \& Kotilainen (2007) describe a similar debrisflow unit in the western Archipelago Sea and in the sub-basins of the northernmost Baltic Sea proper. Those authors also mention occurrences of separate debris-flow deposits in the south-eastern Gulf of Bothnia. It seems that numerous separate debrisflow deposits occur at the same stratigraphic level that is getting younger in the direction of ice retreat in the northern Baltic Sea proper (Virtasalo et al., 2007). Trollskär Formation can, hence, be considered as a discontinuous diachronic unit.

\section{Sandön Formation}

Sandön Formation is named after an island close to the stratotype core AS2-PC4 collection site (Fig. 2). The unit is a lithologic succession composed of a weakly-laminated to homogeneous grey clay facies, which abruptly changes into a monosulphide-banded grey clay facies. The banding grades upward into a diffuse monosulphide-mottled grey clay facies, which grades into a bluish-grey clay facies (Fig. 3). The last two lithofacies are abundant in pyrite-marcasite concretions. The grain sizes are essentially uniform throughout the succession. The unit forms a conformal drape of essentially uniform thickness of 7-8 $\mathrm{m}$ on the underlying topography, with the thickness slightly increasing seaward. The unit is acoustically well-stratified with conformable internal reflectors at its basal part, but is transparent at its top. The top boundary is a strong reflector. In places, the internal reflector structure is truncated at the top boundary, indicating erosion. For details on the sediment physical properties and acoustic characteristics, see Virtasalo et al. (2005).

Sandön Formation is interpreted to have accumulated by fall-out from suspension in a deep freshwater basin (Virtasalo et al., 2007). The relationships of phosphorus forms, reactive iron and organic carbon in these clays indicate that they are derived from several distant sources such as melt waters at the ice front, reworking of older deposits in shallower areas, and river load (Virtasalo \& Kotilainen, 2008). Sedimentary diatom assemblages display moderate production and fresh surface waters (Tuovinen et al., 2008). Ichnofossils reflect intensified bioturbation and increased burrowing depths at the upper part of the unit (Virtasalo et al., 2006). Sandön Formation occurs over wide areas in Archipelago Sea, and can be traced in acoustic profiles to the Gulf of Bothnia, Gulf of Finland, and northern Baltic Sea proper, at least.

\section{Discussion and Conclusions}

The formal stratigraphic division of Late-Quaternary late- and post-glacial sediments in Archipelago Sea is revised. The incorrect definitions of Trollskär Allomember and Sandön Allomember by Virtasalo et al. (2005) are retracted, and these units are formally redefined as the lithostratigraphic units Trollskär Formation and Sandön Formation, respectively (Fig. 2b). Both lithostratigraphic units occur within the unconformity-bounded Korppoo Alloformation. The unconformable lower boundary of Trollskär Formation corresponds to the lower boundary of Korppoo Alloformation, while the unconformable upper boundary of Sandön Formation corresponds to the Korppoo Alloformation top boundary. 
This revision will help avoiding misconceptions concerning temporal relationships and depositional processes at the transition of these two units.

Episodic deposition of Trollskär Formation in Archipelago Sea began at approximately 11100 calendar years before present (cal. BP; Virtasalo et al., 2007), which was during the final freshwater phase of the so-called Yoldia Sea palaeoenvironmental phase of the Baltic Sea basin (e.g. Sauramo, 1958; Ignatius et al., 1981; Heinsalu, 2001; Tuovinen et al., 2008). Similar stratified clast-containing sediment units at a similar stratigraphic position were documented from the Hudson Bay (Hill et al., 1999), the glacial Mazinaw Lake formed along the Laurentide ice sheet (Eyles et al., 2003) and the Permian gondwanan glacigenic Dwyka Formation in South Africa (Visser \& Kingsley, 1982; Visser et al., 1984). These similarities indicate that Trollskär Formation may result from a previously unrecognized (palaeoseismic) process typical for the deglaciation phase of large, low relief, epicontinental basins (Virtasalo et al., 2007). The accumulation of Sandön Formation was more or less continuous, taking place between $10300 \pm 100$ and $7600 \pm 80 \mathrm{cal}$. BP (Virtasalo et al., 2007), which corresponds to a time interval from the early Ancylus Lake phase to the onset of Littorina Sea phase (e.g. Sauramo, 1958; Ignatius et al., 1981; Eronen et al., 2001; Ojala et al., 2005; Tuovinen et al., 2008).

\section{Acknowledgements}

This note was funded by the Alexander von Humboldt Research Fellowship for Postdoctoral Researchers granted for JJV, and by the Inflow project of the Bonus EEIG's Bonus+ call, Academy of Finland. Comments by an anonymous reviewer and the associate editor helped to improve the manuscript.

\section{References}

Eronen, M., Glückert, G., Hatakka, L., van de Plassche, O., van der Plicht, J. \& Rantala, P., 2001. Rates of Holocene isostatic uplift and relative sea-level lowering of the Baltic in the SW Finland based on studies of isolation contacts. Boreas 30, 17-30.

Eyles, N., Doughty, M., Boyce, J.I., Mullins, H.T., Halfman, J.D. \& Koseoglu, B., 2003. Acoustic architecture of gla- ciolacustrine sediments deformed during zonal stagnation of the Laurentide Ice Sheet; Mazinaw Lake, Ontario, Canada. Sedimentary Geology 157, 133-151.

Flint, R.F., 1957. Glacial and Pleistocene Geology. John Wiley \& Sons, New York, 553 p.

Heinsalu, A., 2001. Diatom stratigraphy and the palaeoenvironmnet of the Yoldia Sea in the Gulf of Finland, Baltic Sea. Annales Universitatis Turkuensis AII Biologica-Geographica-Geologica 144, 1-132.

Hill, P.R., Simard, A. \& Héquette, A., 1999. High-resolution seismic stratigraphy of late Quaternary deposits in Manitounouk Sound, northern Quebec: effects of rapid postglacial emergence. Canadian Journal of Earth Sciences 36, 549-563.

Hutri, K.-L. \& Kotilainen, A., 2007. An acoustic view into Holocene palaeoseismicity offshore southwestern Finland, Baltic Sea. Marine Geology 238, 45-59.

Ignatius, H., Axberg, S., Niemistö, L. \& Winterhalter, B., 1981. Quarternary geology of the Baltic Sea. In: Voipio, A. (ed.) The Baltic Sea. Elsevier Oceanography Series 30, 54-104.

Kotilainen, A. \& Hutri, K.-L., 2004. Submarine Holocene sedimentary disturbances in the Olkiluoto area of the Gulf of Bothnia, Baltic Sea: a case of postglacial palaeoseismicity. Quaternary Science Reviews 23, 1125-1135.

NACSN = North American Commission on Stratigraphic Nomenclature, 2005. North American stratigraphic code. AAPG Bulletin 89, 1547-1591.

Ojala, A.E.K., Heinsalu, A., Saarnisto, M. \& Tiljander, M., 2005. Annually laminated sediments date the drainage of the Ancylus Lake and early Holocene shoreline displacement in central Finland. Quaternary International 130, 63-73.

Räsänen, M.E., Auri, J.M., Huitti, J.V., Klap, A.K. \& Virtasalo, J.J., 2009. A shift from lithostratigraphic to allostratigraphic classification of Quaternary glacial deposits. GSA Today 19 (2), 4-11.

Sauramo, M., 1958. Die Geschichte der Ostsee. Annales Academiae Scientiarum Fennicae A III 5, 1-522.

Tuovinen, N., Virtasalo, J.J. \& Kotilainen, A.T., 2008. Holocene diatom stratigraphy in the Archipelago Sea, northern Baltic Sea. Journal of Paleolimnology 40, 793-807.

Visser, J.N.J. \& Kingsley, C.S., 1982. Upper Carboniferous glacial valley sedimentation in the Karoo Basin, Orange Free State. Transactions of the Geological Society of South Africa 85, 71-79.

Visser, J.N.J., Colliston, W.P. \& Terblanche, J.C., 1984. The origin of soft-sediment deformation structures in PermoCarboniferous glacial and proglacial beds, South Africa. Journal of Sedimentary Petrology 54, 1183-1196.

Virtasalo, J.J., 2006. Late-Weichselian - Flandrian depositional history of the Archipelago Sea, northern Baltic Sea. Annales Universitatis Turkuensis AII Biologica-Geographica-Geologica 196, 1-156.

Virtasalo, J.J. \& Kotilainen, A.T., 2008. Phosphorus forms and 
reactive iron in lateglacial, postglacial and brackish-water sediments of the Archipelago Sea, northern Baltic Sea. Marine Geology 252, 1-12.

Virtasalo, J.J., Kotilainen, A.T. \& Räsänen, M.E., 2005. Holocene stratigraphy of the Archipelago Sea, northern Baltic Sea: the definitions and descriptions of the Dragsfjärd, Korppoo and Nauvo Alloformations. Baltica 18, 83-97.

Virtasalo, J.J., Kotilainen, A.T. \& Gingras, M.K., 2006. Trace fossils as indicators of environmental change in Holocene sediments of the Archipelago Sea, northern Baltic Sea. Palaeogeography, Palaeoclimatology, Palaeoecology 240, 453-467.

Virtasalo, J.J., Kotilainen, A.T., Räsänen, M.E. \& Ojala, A.E.K., 2007. Late-glacial and post-glacial deposition in a large, low relief, epicontinental basin: the northern Baltic Sea. Sedimentology 54, 1323-1344. 